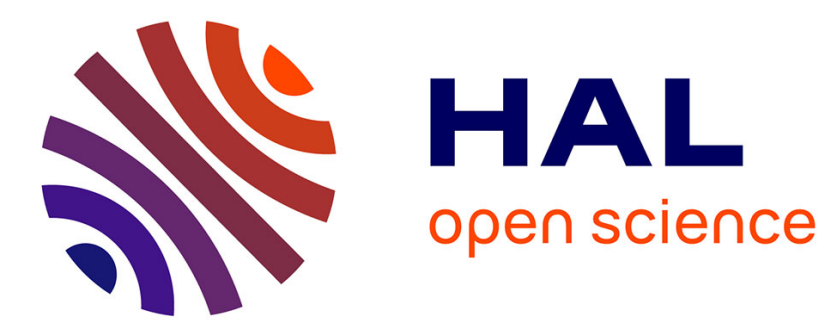

\title{
Priority effects: Emerging principles for invasive plant species management
}

Manon C.M. Hess, François Mesléard, Elise Buisson

\section{To cite this version:}

Manon C.M. Hess, François Mesléard, Elise Buisson. Priority effects: Emerging principles for invasive plant species management. Ecological Engineering, 2019, 127, pp.48-57. 10.1016/j.ecoleng.2018.11.011 . hal-01927314

\section{HAL Id: hal-01927314 https://hal.science/hal-01927314}

Submitted on 21 Nov 2018

HAL is a multi-disciplinary open access archive for the deposit and dissemination of scientific research documents, whether they are published or not. The documents may come from teaching and research institutions in France or abroad, or from public or private research centers.
L'archive ouverte pluridisciplinaire HAL, est destinée au dépôt et à la diffusion de documents scientifiques de niveau recherche, publiés ou non, émanant des établissements d'enseignement et de recherche français ou étrangers, des laboratoires publics ou privés. 
(1)

Review

\section{Priority effects: Emerging principles for invasive plant species management}

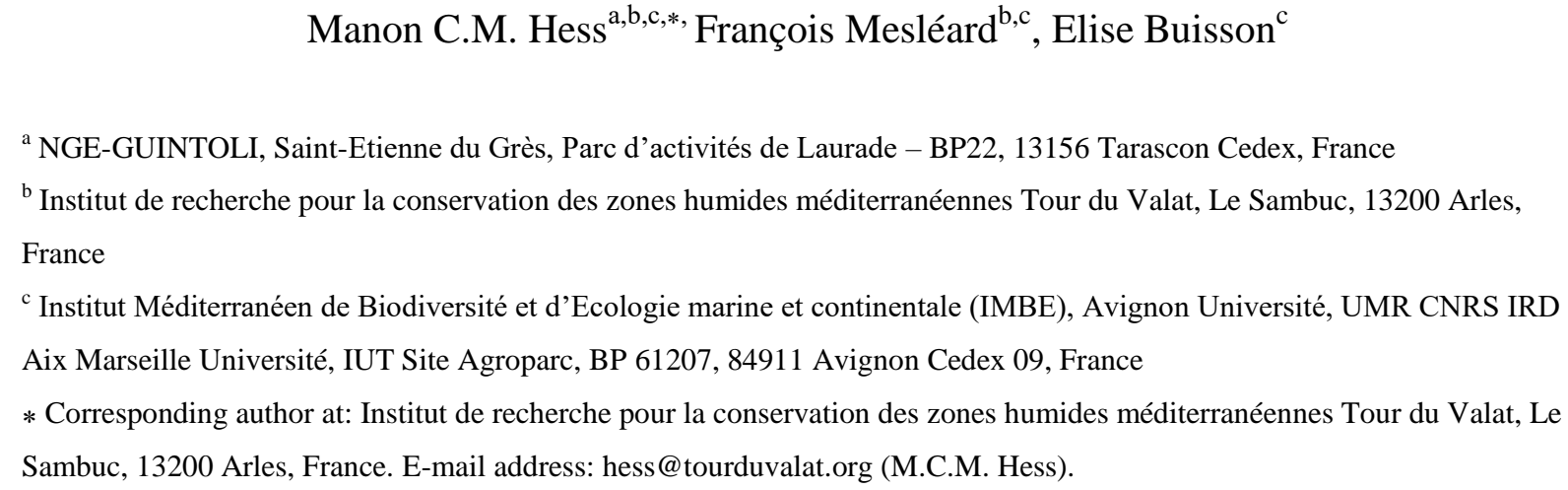

Keywords: Invasion resistance; Restoration; Community assembly history; Historical contingency; Order of arrival; Legacy

\section{Abstract}

Many anthropic activities generate soil disturbances, favoring competitive, fast growing invasive plant species at the expense of natives. Active restoration of invasionresistant plant communities is increasingly recognized as a relevant strategy to combat invasive plant colonization in disturbed areas, but results are often unsatisfying. Historical effects, referred as "priority effects" (i.e. the effects generated by the order in which species arrive at a local site), can have a major role in community assembly and invasion success because they involve early colonists altering the performance of later colonists. Taking these priority effects into account in restoration projects is emerging as a relevant way to improve native species restoration success and prevent invasion. The present review discusses two strategies considering priority effects that would help to achieve the classic restoration goal of "more natives, less invasives". The first strategy relies on tackling priority effects of invasive plants using different management options adapted to local environmental conditions, including removal, reduction of propagule sources, or mitigation of soil legacies. Indeed, invasive plants often generate strong priority effects providing themselves a substantial 
competitive advantage through early emergence and quick growth, but also self-induced soil modifications that can persist after their removal or death, commonly termed "soil legacies". In fertile and stable conditions, the reduction of invasive species priority effects must be coupled with the restoration of an invasion-resistant native plant cover to avoid reinvasion and secondary invasions. The second strategy is to bring about situations in which the restored native species are more likely to exert strong priority effects, decreasing invasion success. For this purpose, we sketch possible options open to restorationists based on resource or nonresource mechanisms. First, we discuss ways to maximize resource preemption by extending the time advance given to restored native species and manipulating restored species characteristics. Second, we consider the potential effect of increasing niche overlap between native and invasive species. Third, we introduce the potential manipulations of non-resource mechanisms, such as allelopathy, herbivory, disease, or the presence of mycorrhizae, to increase priority effects. This review incorporates recent research on priority effects to draw the outlines of priority effects-based restoration strategies and define future research questions that need to be addressed to test and improve these strategies.

\section{Introduction}

The vast literature on biological invasions since Elton's seminal work (1958) testifies to the complexity of understanding the processes underlying invasion success (Levine et al., 2003; Hayes and Barry, 2008; Simberloff, 2013). According to deterministic theories, the outcome of an invasion depends on interactions between the invader and the physical and biological characteristics of the recipient environment (Lonsdale, 1999; Williamson, 1999). The intrinsic competitive superiority of invasive plant species (i.e. species introduced outside of their distribution areas which are able to grow and proliferate to become an autonomous viable population, and whose expansion can negatively impact local species and ecosystems; Richardson et al., 2000; Mooney, 2005) in acquiring resources has long been considered the critical mechanism determining invasion success (Sax and Brown, 2000; Vila and Weiner, 2004; Pyšek and Richardson, 2008). However, invasive species performance also appears to depend on the physical and biological conditions encountered in the introduced range: resource availability and fluctuation (Davis et al., 2000; Shea and Chesson, 2002; Firn et al., 2010; D'Antonio et al., 2017), multi-trophic interactions involving enemies (Mitchell et al., 2006), and resident plant community composition (Levine and D'Antonio, 1999; Fridley et al., 2007). In addition to the deterministic explanations, stochastic dispersal and historical processes also play a crucial role in determining invasion success (Hubbell, 2001; Kolar and 
Lodge, 2001; Chase, 2003; Lockwood et al., 2005; Dickson et al., 2012; Wilsey et al., 2015; Young et al., 2015).

Stochastic colonization combined with deterministic interactions between early and later colonizing species lead to priority effects (Case, 1990; Chase and Myers, 2011), where early-arriving species affect the establishment, survival, growth or reproductive success of later-arriving species (Helsen et al., 2016). There is growing evidence that priority effects play a crucial role in community assembly, especially in productive environments (Chase, 2003; Aronson and Galatowitsch, 2008; Körner et al., 2008; Young et al., 2016) and can be implicated in invasion success (Seabloom et al., 2003; Corbin and D'Antonio, 2004; Abraham et al., 2009; Grman and Suding, 2010). One mechanism prevalent in priority effects is resource preemption (Young et al., 2001; Fukami, 2015): the reduction of available resources (e.g. space, light, nutrients) by the early colonizers (Vance, 1984). This mechanism may allow even weak competitors to persist and maintain long-term dominance (Ross and Harper, 1972; Chase, 2010). Priority effects also arise from alterations of biotic (e.g. soil microorganisms) and abiotic (e.g. nutrient dynamics, allelochemicals) components of the environment, which can, in some contexts, limit colonization by subsequent colonizers (Kourtev et al., 2002; Mangla and Callaway, 2008; Corbin and D'Antonio, 2012). Disturbances leading to the removal of most or all plant individuals in a habitat patch initiate a new round of community assembly (Fukami, 2015), often favoring competitive, fast growing invasive species at the expense of natives (Hobbs and Huenneke, 1992; Davis et al., 2000). Because of the wellrecognized issues raised by invasive species (i.e. human health, crop production, native biodiversity, economic; Vitousek et al., 1997; Kolar and Lodge, 2001; Simberloff, 2013) and because of the evolution of legal framework on invasive species (at least in Europe; Regulation (EU) No 1143/2014), there is clearly an urgent need to develop effective strategies to limit invasions, particularly in newly disturbed areas. However, although active restoration of plant communities is increasingly recognized as a relevant tool to combat invasions (Middleton et al., 2010; Hazelton et al., 2014; Byun and Lee, 2017), results are often far from satisfactory (Kellogg and Bridgham, 2002). This has notably been attributed to a failure to account for priority effects, which may play a decisive role in restoration success (Young et al., 2001; Temperton, 2004; Grman and Suding, 2010; Wilsey et al., 2015). Priority effects appear to offer a cost-effective approach to combatting invasive plant species (Chadwell and Engelhardt, 2008), but have only been recently considered for invasive species management. Here, we discuss two non-exclusive restoration strategies to achieve the end goal "more natives, less invasives". The first strategy consists in tackling priority effects generated by 
invasive species, while the second is to bring about situations in which the native species are more likely to exert strong priority effects.

\section{Dealing with invasive species priority effects}

\subsection{Priority effects are particularly advantageous to invasive species}

Phenological differences between invasive and native species can substantially contribute to invasion success (Wolkovich and Cleland, 2011). Distinct phenology allows certain invasive species to fill vacant phenological niches and profit from temporally available space and resources (e.g. light, nutrients, pollinators), sometimes creating seasonal priority effects (i.e. priority effects operating seasonally on a within-year scale; Wolkovich and Cleland, 2011). Numerous invasive species shares the strategy of being active early in the season as to get an early access to resources and acquire a competitive dominance (Dyer and Rice, 1997; Seabloom et al., 2003; Munter, 2008; Wolkovich and Cleland, 2011), but others also profit of being active late in the season (e.g. in California, the invasiveness of Centaurea silsitialis arises from extending its growing season into the summer when competition from winter annual vegetation for soil water is minimal; Gerlach and Rice, 2003).

Several studies reported that invasive species generate stronger priority effects than natives (Dickson et al., 2012; Wilsey et al., 2015; Stuble and Souza, 2016, but see Cleland et al., 2015). The generally higher growth rate of invasive species (Rejmánek and Richardson, 1996; Reynolds et al., 2001; Grotkopp et al., 2010; Marushia et al., 2010; Dawson et al., 2011) was suggested to underlie this advantage (Stevens and Fehmi, 2009; Dickson et al., 2012). A higher growth rate creates a greater asymmetry in plant size (Weiner, 1990), resulting in a stronger competitive suppression of the later arriving species (Dyer and Rice, 1999; Perry et al., 2003; Ejrnaes et al., 2006). Cleland et al. (2015) found that the stronger priority effects of invasive species were correlated to regeneration trait values, such as higher germination rate and higher light capture during seedling stage, reflecting higher biomass.

In addition to these seasonal advantages, invasive species can also profit from priority effects through self-induced soil condition modifications, whether biological, chemical or physical (Corbin and D'Antonio, 2012). Modifications such as: (1) shifts in nutrient cycling (Ehrenfeld, 2003; Marchante et al., 2008; Flinn et al., 2017) and soil salinity (Novoa et al., 2013), (2) changes in soil microbial communities including pathogens and mycorrhizal fungi (Kourtev et al., 2002; Hawkes et al., 2006; Mangla and Callaway, 2008; Stinson et al., 2006; Kardol et al., 2007; Lorenzo et al., 2010), and (3) the release of allelochemicals (Bais et al., 2003; Stinson et al., 2006; Milchunas et al., 2011; Grove et al., 2012) can all generate priority 
138 Reinhart and Callaway, 2006; Stinson et al., 2006; van der Putten et al., 2013; Rodriguez-

139 Echeverria et al., 2013; Meisner et al., 2014). Such invader-mediated soil modifications can

140 persist after the causal invasive species is removed or dies (Corbin and D'Antonio, 2012;

141 Hacker and Dethier, 2009; Hamman and Hawkes, 2013), and are commonly termed "soil

142 legacies" (Fig. 1B).

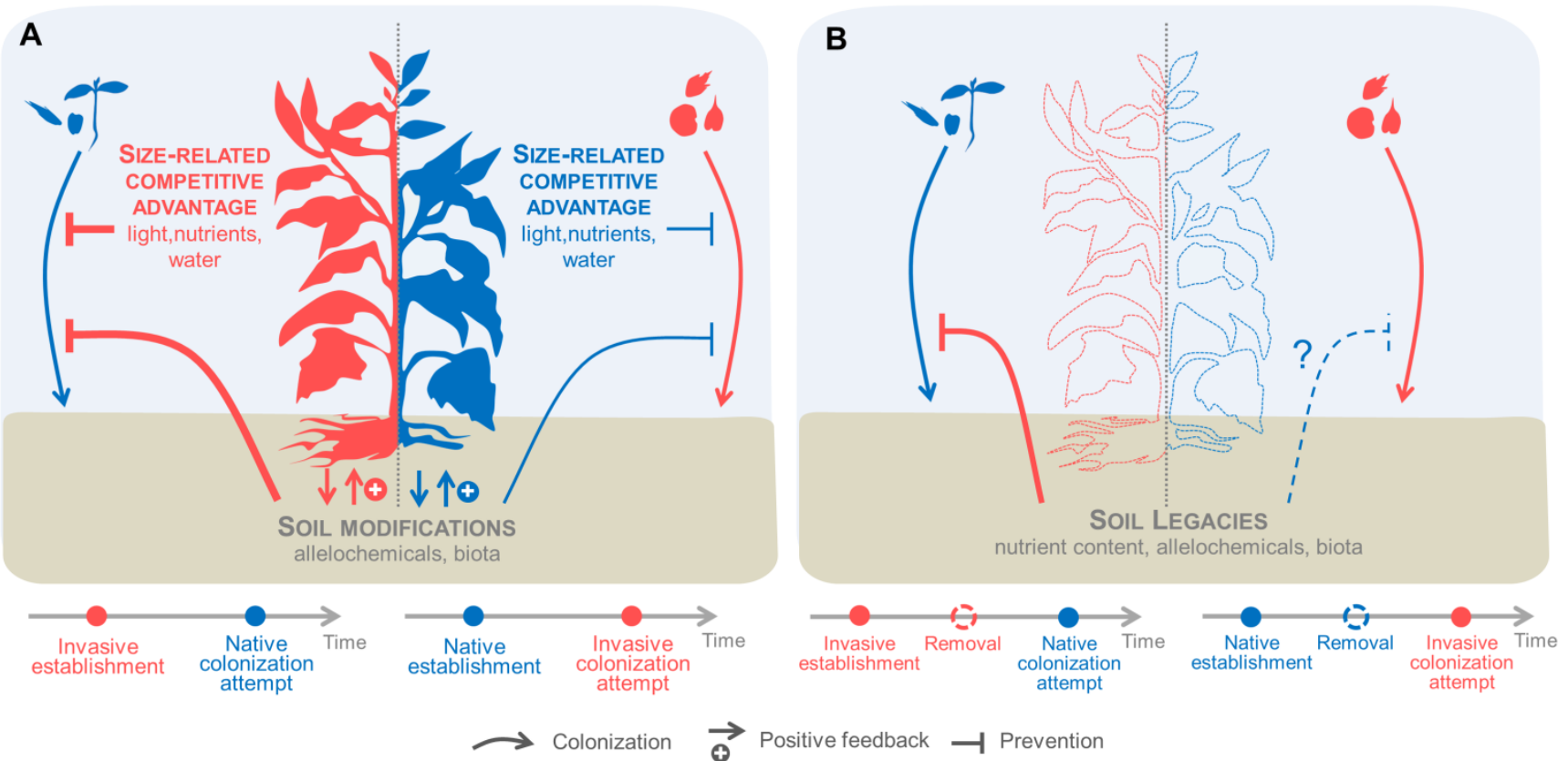

143 Fig. 1. Mechanisms driving the consequences of priority effects when the plant individual is present (A), or has been

144 removed or died (B). (A) Early arriving species can limit colonization success of subsequent colonizing species by gaining a size-related competitive advantage, by generating positive plant-soil feedbacks improving its own performance, and by modifying soil conditions. Priority effects are asymmetric between native and invasive species, so that invasive species are less impacted by arriving late compared with natives. (B) Plants can also generate priority effects through soil legacies after they were removed or died, that can impact subsequent colonization. While, for many invasive species, persistent soil legacies have been reported to hinder invasive recolonization, little is known about how native species soil legacies could limit invasive species establishment. Note that Grman and Suding (2010) found no impact of native species legacies on invasive species success.

152

\subsection{Countering invasive species priority effects}

When it comes to decrease the competitive dominance of an invasive plant species, it is essential to look for abiotic conditions to determine what actions need to be undertaken. In environments with high nutrient resource and water availability, the presence of invasive species could particularly hinder restoration of native communities because of their high competitive abilities (Cox and Allen, 2008; Abraham et al., 2009; Grman and Suding, 2010). Countering invasive species competitive advantage can be achieved by applying intensive management techniques to reduce invasive species cover (i.e. herbicide applications, 
mechanical removal; Fig. 2). Marushia et al. (2010), by applying control methods (herbicide application) early in the season, tackled rapid and early emerging exotic annuals while minimizing impacts on native plants. In favorable conditions, many invasive species are likely to invade in response to the removal of one or more invaders (D'Antonio et al., 2017). Thus, it is particularly relevant to reduce propagule sources in order to limit invasive species recolonization (Fig. 2; D'Antonio et al., 2017). Common methods to decrease nondesirable species seed bank include topsoil removal (Hölzel and Otte, 2004), effective mowing management (i.e. adjusted to phenological development; Milakovic et al., 2014) and artificial flushing of invasive species to induce germination, followed by lethal interventions such as tillage or herbicide application (Wolf and Young, 2016). Prescribed burns for fire-prone species or supplying water are two techniques promoting germination (Ooi, 2007; Wolf and Young, 2016) that could be used to flush invasive plant species and tackle seasonal priority advantage early in the season (Wolkovich and Cleland, 2011; Wainwright et al., 2012; Wilsey et al., 2015). Establishing early-emerging and competitive native species (e.g. cover crops) is another option that can help reducing competition from early-germinating invasive species. Indeed, restoring early-emerging species can directly decrease invasive species performance (Blackshaw et al., 2006) and indirectly favor desired native species (Perry et al., 2009). However, so far, these strategies are little explored. To successfully counter seasonal priority effects generated by invasive species, it is crucial to better understand invasive species phenology, requirements and possible interactions with native species, so as to improve existing management techniques (i.e. artificial invasive species flushing, the use of cover crops) and develop new ones.

To limit reinvasion and secondary invasions, invasive species reduction must be coupled with revegetation strategies (Fig. 2; Pearson et al., 2016) directed towards the limitation of multiple co-occurring invasive plant species. However, because of soil legacies, invasive species removal and propagule pressure reduction are sometimes unlikely to lead to recovery of native communities (Suding et al., 2004; Ehrenfeld et al., 2005; Corbin and D'Antonio, 2012; Jordan et al., 2012; van der Putten et al., 2013), and often favor secondary invasions (Dickie et al., 2014; Grove et al., 2015; Yelenik and d'Antonio, 2013). When the site was invaded prior to disturbance, it may then be necessary to include measures to deal with soil legacies, rather than simply eliminate invasive species populations (Fig. 2). Soil legacies can be mitigated by adjusting soil properties, typically via topsoil removal or soil amendments (Kulmatiski and Beard, 2006; Buisson et al., 2008; Perry et al., 2010). Carbon addition can help lowering nitrogen availability by stimulating nitrogen immobilization (Baer 
et al., 2003), thereby reducing invasive species performance and concurrently increasing desired species growth (Alpert and Maron, 2000; Blumenthal et al., 2003; Eschen et al., 2007; see Perry et al., 2010 for review). However, in the case of restored communities reassembling from seeds, nitrogen management may have no direct positive effect unless a headstart is given to natives (i.e. invasive species are controlled the first growing season; James et al., 2011). Furthermore, success of carbon addition to decrease invasive species dominance also mainly depends on the condition that invasive species is nitrophilic relative to native species (Blumenthal et al., 2003).

To face soil legacies, another restoration approach is to establish species that are tolerant to invasive species legacies (Perry et al., 2005), or that could mitigate legacies before establishing the target community (Jordan et al., 2008; Eviner and Hawkes, 2012; Leger et al., 2015; Vink et al., 2015). In this sense, restoration of non-susceptible species to Centaurea maculosa's allelopathic compounds prevented reinvasion and possibly facilitate native species recovery (Callaway et al., 2005; Thorpe et al., 2009). Herron et al. (2001) also showed that establishing native species decreasing nitrogen availability through high nitrogen uptake decreases the prevalence of invasive species favored by soil nitrogen enrichment.

Taking soil legacies into account in restoration projects is however challenging. Soil legacies are difficult to predict and to assess (involving chemical analyses, determination of microbial communities' abundance and composition), and are species-specific (Bezemer et al., 2006; Yelenik et al., 2007; Bardgett and Wardle, 2010). Furthermore, their persistence depends on characteristics of the invaded ecosystem (e.g. soil mineralization rates; Stock et al., 1995), on their nature (Levine et al., 2003; Corbin and D'Antonio, 2012), and on the duration of invasion (Marchante et al., 2008; Kulmatiski and Beard, 2011). For example, while allelopathic compounds are generally short-lived in the soil (i.e. hours to days; Blair et al., 2005; Reigosa et al., 2006), increased nitrogen levels generated by a nitrogen-fixing invasive species can persist for decades (e.g. 35 years; Maron and Jeffries, 2001). Long-term studies suggest, however, that invasion impacts on ecosystems, such as increased nitrogen levels, can shift over time (Yelenik and D’Antonio, 2013). All this makes it hard to predict the amplitude and persistence of soil legacies for a particular invasive species in a given environment, and calls for high levels of costly technical expertise. Thus, soil legacies are not systematically given the weight they deserve in restoration projects. Yet restoration would clearly benefit from accounting for soil legacies, especially when an invasive species is implicated in strong and persistent legacies and has dominated the target environment for several growing seasons (Fig. 2; Marchante et al., 2008; Kulmatiski and Beard, 2011). A 

habitat they commonly invade would reduce the need for complex and expensive analyses, facilitating development of effective restoration strategies. Cost-effective methods, such as developed to rapidly assess their extent.

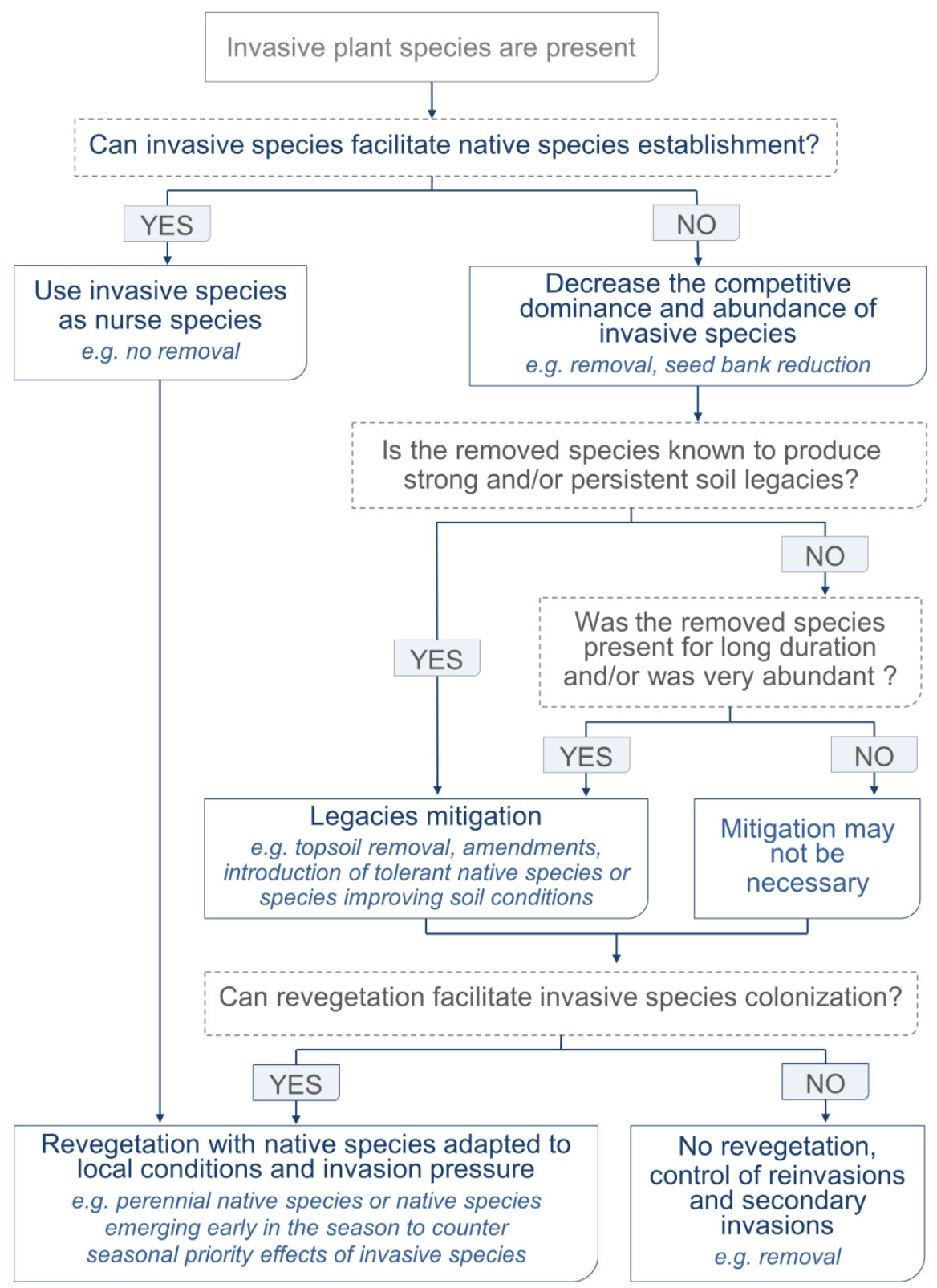

233 Fig. 2. Decision support to counter invasive plant species priority effects. When invasive species facilitate the establishment of natives (e.g. in some harsh environments), they should not be removed and can be used as nurse species for restored species. Conversely, when invasive species hinder native species establishment (e.g. in some fertile and stable environments), it is essential to decrease their abundance and prevent secondary invasions, notably via removal and seed bank reduction. After removal, soil legacies generated by invasive species can lower restoration success. These legacies should be particularly considered when the removed invasive species is known to produce 
strong and/or persistent legacies (e.g. nitrogen levels), and/or or was present in abundance and/or for long duration. Legacies mitigation methods such as topsoil removal, amendments (e.g. carbon addition), or intermediate planting should be adjusted to the nature and intensity of legacies. Finally, the restoration of native species adapted to local conditions and invasion pressure should be undertaken to limit reinvasion and secondary invasions, except when revegetation facilitates invasions (e.g. in some harsh environments).

In harsh environments with extremely limited resources and/or stressful conditions (e.g. extreme temperatures, excessive solar radiation, unstable substrates), invasive species removal often lead to a lower success of a native cover restoration (D'Antonio and Meyerson, 2002). In some cases, invasive species are used as nurse plants to facilitate the establishment of native species (Fig. 2; Becerra and Montenegro, 2013; Hanslin and Kollmann, 2016). The removal of an invasive species may not result in additional invasions (D’Antonio et al., 2017): the likelihood of other stress-adapted species being present and able to respond quickly is low (Harms and Hiebert, 2006), and these systems constrain species to low productivity or capacity to accumulate biomass (D’Antonio et al., 2017). Managers may therefore have ample time to control a secondary invasive species because they commonly have low population growth rates (Funk and Vitousek, 2007).

\section{Strengthening native species priority effects}

Restoring native communities after a disturbance can have opposite consequences on invasion success depending on abiotic conditions. In harsh environments, native species can create microclimatic conditions that are more favorable to invasive species establishment than the surrounding (Lenz and Facelli, 2003; Cavieres et al., 2005; Mason et al., 2013). In such cases, the restoration of a vegetation cover may not be the best option. Removal of invasive species followed by the control of secondary invasions without active revegetation may be a more suitable strategy. Resource availability, especially nitrogen, also strongly influences invasion success through modifications in competition intensity between species (Davis et al., 2000; Davis and Pelsor, 2001). Environmental harshness has also been assumed to decrease the importance of stochastic factors because of strong niche selection (Chase, 2007; Kardol et al., 2013). In this sense, Kardol et al. (2013) found weaker priority effects under low nutrient supply. In nitrogen-limited systems, restoration of nitrogen-fixing species can also favor the establishment of fast-growing invasive species that overgrow and shade slower-growing native species (Huenneke et al., 1990; Maron and Connors, 1996; Corbin and D'Antonio, 2004b). In such conditions, it may be advisable to restore a native plant cover adapted to low levels of nitrogen and to consider avoiding nitrogen-fixing species and soil nitrogen amendments. 
In fertile and relatively stable conditions, restoration of invasionresistant native plant

species is increasingly considered to protect disturbed sites from re-invasion or secondary invasions (Perry and Galatowitsch, 2006; Buckley, 2008; Middleton et al., 2010; Byun et al., 2013; Pearson et al., 2016). Environmental conditions influence the magnitude of priority effects (Collinge and Ray, 2009; Kardol et al., 2013; Symons and Arnott, 2014), with stronger impact in productive environments (Kardol et al., 2013; Young et al., 2016). The strength of priority effects also varies with the identity of the earlier- and the laterarriving species (Dickson et al., 2012; von Gillhaussen et al., 2014; Cleland et al., 2015; Wilsey et al., 2015; Stuble and Souza, 2016), invasive species being less negatively impacted by arriving late than native species (Fig. 1A; Wilsey et al., 2015; Stuble and Souza, 2016), raising the need to restore native species producing strong priority effects.

Recent work on priority effects also states that the strength of priority effects is notably driven by (1) the impact a species has on resource levels (Fargione et al., 2003; Fukami, 2015), (2) the overlap between competitive species in resource needs (Funk et al., 2008; Vannette and Fukami, 2014), and (3) the impact a species has on nonresource components of the environment (Bever, 2003; Levine et al., 2004; Goldstein and Suding, 2014). The following sections will discuss how these emerging properties could be used to reinforce the priority effects of restored native species in invaded habitats (see Figure A1 in Appendix for summary).

\subsection{Increasing resource preemption}

\subsubsection{Does the duration of time advance matters?}

Numerous studies reported that giving native species a short time advance (one to few weeks) suffices to substantially decrease invasion success in grassland systems (Firn et al., 2010; Grman and Suding, 2010; Vaughn and Young, 2015; Young et al., 2016). Grman and Suding (2010) found that native species establishment only five weeks before invasive species introduction reduced invasive biomass by $85 \%$, against an $8 \%$ decrease when natives and invasives were planted simultaneously. Firn et al. (2010) also found a strong effect of giving a threeweek head-start to native grasses on an invasive grass performance. However, few studies investigated the importance of the duration of the time interval between native establishment and invasive species colonization. Asymmetry in plant size has been advocated as one of the most important aspect of priority effect (Wilsey et al., 2015), suggesting that extending duration interval between native species establishment and the later invasion event may give a size advantage strengthening native priority effects. In this sense, von Gillhaussen 
et al. (2014) found that a six-week head-start resulted in stronger priority effects than a threeweek head-start. Young et al. (2016) tested the effect of giving the native perennials a twoweek or a one-year seeding advantage over exotic annuals in a four-year experiment. It respectively resulted in a native cover increase of $68 \%$ or $128 \%$ compared to when natives and exotics were sown at the same time. The positive effect of increasing time advance appeared however inconstant between years and sites, with sometimes an absence of benefit. Better understand how the duration of time advance given to the restored native species influence invasion success would be crucial to develop cost-effective priority effects- based revegetation strategies. To give natives a time advantage over invasives, native species should be actively restored as soon as possible after the disturbance on an invasive species-free soil (Stevens and Fehmi, 2009), and a particular attention must be payed to invasive species control in the initial weeks. Providing a short-term priority (several days) could also be achieved by "pre-germinating" native species seeds. Pre-treatments including seed priming and cold stratification can help ensuring a rapid and complete germination and overcome seed dormancy (Halmer, 2004). These treatments therefore appear as opportunities for improving native emergence speed and create priority effects over invasives, but remain yet untested.

Although the eventual success of extending time advance can be judged only against the persistence of priority effects over long periods (i.e. more than one growing season), longterm studies are rare. Vaughn and Young (2015) showed that the effect of a two-week advance in planting can remain visible after three years, favoring native perennials over exotic annuals. Werner et al. (2016) highlighted differences in persistence of a one-year priority between functional groups: the grass priority over forbs was still visible after six to eight years, but the forb priority over grasses did not persist. Designing efficient, cost-effective restoration strategies that allow native species to maintain their dominance over invasive species in the long term calls for more studies on mechanisms (i.e. duration of time advance, disturbance regime, resource availability, dynamic of sown communities) influencing the persistence of priority effects over long periods.

\subsubsection{Manipulate species composition and density}

The resource competition model (Tilman, 1990) predicts that the more a species reduces the availability of limited resources, the less these resources are available for later colonizers. Because resource preemption has been identified as one of the main driver of priority effects (Fukami, 2015), high resource preemption would lead to strong priority effects (Vannette and Fukami, 2014). Fargione et al. (2003) found that C4-grasses inhibited the most the later arriving invasive species, most likely because this guild reduced soil nitrate to the 
lowest levels compared with other tested functional guilds. This result suggests that restoring native species leading to a strong and rapid reduction of limited resources could help enhancing priority effects. Accordingly, research efforts should be directed towards the identification of species having the ability to (1) rapidly occupy of above- and/or belowground space, thereby limiting light and space availability (often considered as two primary determinants of invasive species germination and establishment; D'Antonio et al., 2001; Corbin and D'Antonio, 2004a; Iponga et al., 2008), and (2) rapidly and effectively preempt soil nutrients, especially in low productivity environments where there is likely to be less above-ground competition for light (Dietz and Edwards, 2006; Gioria and Osborne, 2014).

At small scale $\left(10 \mathrm{~m}^{2}\right.$ or less), many studies support the widespread assumption that species diversity confers invasion resistance (Tilman, 1997; Levine and D'Antonio, 1999; Levine et al., 2004; Carter and Blair, 2012), due to fuller use of resources by resident species (“complementarity effect”; Robinson et al., 1995; Lavorel et al., 1999; Levine and D'Antonio, 1999; Larson et al., 2013), or due to the increased probability of a species being present to be a strong competitor for the invasive species when increasing the number of species in a community ("sampling effect": Kennedy et al., 2002; Wardle, 2001; Lavorel et al., 1999; Goslee et al., 2013). Increasing diversity has been reported to increase primary productivity in grassland systems (Hector et al., 2011), suggesting that diverse communities produce higher rates of biomass and could therefore exert a stronger asymmetric competition with later colonists. Two studies supported the fact that diversity strengthens priority effects in protist and aquatic plant communities (Jiang et al., 2011; Viana et al., 2016), but more studies investigating this relationship in plant communities are needed.

The density of individuals also modulates priority effects (Weiner, 1990) in the sense that establishing more individuals should lead to increased resource acquisition and competition intensity (Goldberg, 1990; Lockwood et al., 2005). The benefit of increasing sowing density may stabilize over time, since the law of constant yields predicts that evenaged populations grown at different densities show the same overall productivity after a certain period of time, with higher number of individuals in high densities but lower standing biomass per individual (Drew and Flewelling, 1979). Consistently, von Gillhaussen et al. (2014) found sowing density $\left(1.5,2.5\right.$ and $\left.5 \mathrm{~g} / \mathrm{m}^{2}\right)$ only had a weak influence on aboveground productivity. Increased density is however often associated with improved invasion resistance in short time scales (Gerhardt and Collinge, 2007; Carter and Blair, 2012; Vaughn and Young, 2015; Yannelli et al., 2017). Accordingly, Yannelli et al. (2017) found that sowing communities at high density $\left(10 \mathrm{~g} . \mathrm{m}^{2}\right)$ is more effective in suppressing invasive species than 
374 low density $\left(1 \mathrm{~g} . \mathrm{m}^{2}\right)$. The improved invasion-resistance of high density community may be related to the inability of low density community to fully exploit available resources. Since we are looking for solutions to design restored communities rapidly exerting strong priority effects, increasing sowing densities is an attractive option. However, it remains to determine effective sowing thresholds depending on species used and environmental conditions.

\subsection{Increasing niche overlap: Applying limiting similarity}

Niche overlap, referring to resource use similarity between co-occuring species independent of their rate of resource consumption (Pianka, 1974; Petraitis, 1989), has been hypothesized to influence invasion-resistance (Abrams, 1983; Funk et al., 2008) and more recently priority effects (Vannette and Fukami, 2014). Niche overlap is derived from the limiting similarity concept, predicting that species most similar to the invasive species should provide greater invasion resistance because of greater overlap in resource use (Abrams, 1983). Accordingly, a high degree of similarity in resource use between first and later colonizers should strengthen priority effects of the recipient species. Attempts to use limiting similarity to limit plant invasions often resulted in failures (Symstad, 2000; Emery, 2007; Turnbull et al., 2005; Price and Pärtel, 2013), highlighting the complexity of selecting plant species having a sufficient degree of niche overlap. With current knowledge, using the limiting similarity concept to limit invasions appears premature. An emerging, more promising strategy consists in focusing on the identification of key functional traits playing a substantial role in invasion resistance and priority effects (Drenovsky and James, 2010; Cleland et al., 2013). For example, Cleland et al. (2013) identified phenology as an important determinant of invasion success: high phenological overlap between exotic annual grasses and restored forb species successfully resulted in a decreased abundance of invasive species. These results suggest that restoring early active perennial species may be particularly relevant to decrease the competitive dominance of early active annual invasive species in the long term. Further investigations are needed to determine how and in which situations such trait-based strategies are efficient.

\subsection{Manipulating non-resource components}

Few studies have explored ways to enhance invasion-resistance of restored communities by exploiting non-resource priority effects (Bever, 2003; Levine et al., 2004) induced by the release of allelopathic compounds, the manipulation of mycorrhizae, or the promotion of pathogens or herbivory (Goldstein and Suding, 2014). Non-resource priority 
effects could act through a direct negative impact on the target invasive species, or by an indirect improvement of native species success.

The use of allelopathy (i.e. the exudation of chemical compounds influencing the growth of other plants or microorganisms) for invasive species control has received special attention, especially in suppressing weeds in agricultural systems (Bhowmik, 2003; Milchunas et al., 2011; Jabran et al., 2015; Jabran, 2017). The establishment of native allelopathic species can directly reduce the biomass of the target invasive species (Callaway and Ridenour, 2004), and indirectly facilitate the desired later-arriving native species (Perry et al., 2009). Indeed, allelopathy is relatively ineffective in interactions between species that frequently co-occur (Fitter, 2003) and is more intense in novel interactions, such as between native and exotic species (Callaway and Ridenour, 2004; Thorpe et al., 2009). By being established first, native allelopathic species could induce stronger priority effects reducing invasion success, but such assumption needs to be tested. Since the allelopathic effect vary depending on species (Prati and Bossdorf, 2004), community density (Weidenhamer et al., 1989), climate conditions (May and Ash, 1990; Blair et al., 2006), and substrate characteristics (Parepa and Bossdorf, 2016), using allelopathic native species to limit invasion appears complex and may be limited to a set of invasive species. The effectiveness of invasive control strategies based on allelopathic species needs further investigations, in particular the potential use of native allelopathic species to suppress several invasive species.

In addition to plant-plant interactions, biotic resistance can also arise from consumption by herbivores and disease (Levine et al., 2004). Introducing coevolved natural predators or parasites from the native region of the invasive species has been implemented for controlling well-established invasive populations, with mixed results (Clewley et al., 2012). Native herbivores can have various impacts on invasives (Maron and Vilà, 2001; Levine et al., 2004), sometimes contributing (i.e. invasive plants are maladapted to deter consumption by native herbivores; Parker and Hay, 2005; Morrison and Hay, 2011; Petruzzella et al., 2017; Zhang et al., 2018) or not (i.e. native herbivores are maladapted to consume invasive plants; Keane and Crawley, 2002; Liu and Stiling, 2006; Xiong et al., 2008) to biotic resistance. However, because herbivores have been reported to create disturbances facilitating the establishment of invasive species (Mack, 1989; Hobbs and Huenneke, 1992), and because young restored native species may be negatively impacted by trampling (Clear-Hill and Silvertown, 1997), using herbivores in early stages of restoration may not be an advisable option. 
Mycorrhizal fungi, forming symbiotic relationships with $80-90 \%$ of terrestrial plants (Smith and Read, 2008), often strongly influence plant growth and reproduction (Koide and Dickie, 2002), plant community structure (van der Heijden et al., 1998; Hartnett anrd Wilson, 1999, 2002), and invasion success (Klironomos, 2002; Callaway et al., 2004). Soil inoculation of arbuscular mycorrhizal fungi can reduce the performance of agricultural non-mycorrhizal weeds (Jordan et al., 2000; Vatovec et al., 2005; Rinaudo et al., 2010; Veiga et al., 2011), raising a potential application in managing non-hosts invasive species (e.g. from Chenopodiaceae and Cruciferae families; Wang and Qiu, 2006). In the case of non-hosts invasive species, establishing species having the ability to increase mycorrhizal inoculum potential would facilitate arbuscular mycorrhizal fungi-dependent native species (Eviner and Hawkes 2012), and may enhance their competitive abilities over later arriving invasive species (Smith et al., 1998). In the cases where the presence of mycorrhizae increases invasion success of host invasive species (Marler et al., 1999; Smith and Read, 2008), mycorrhizae suppression through fungicide application combined with restoration of nonmycorrhizal species may help limiting invasive species. The feasibility and effectiveness of this approach needs however to be investigated, since mycorrhizae are sometimes essential in some species assemblages (Dostálek et al., 2013).

Overall, whether native herbivores, parasites and symbionts could create priority effects reducing invasive species success remains untested, so that an application in restoration is premature. Because interactions between invasive species and native enemies or symbionts are species or trait-specific (Veiga et al., 2011; Grutters et al., 2017; Zhang et al., 2018), it may be relevant to develop non-resource-based restoration strategies for the most noxious invasive species.

\section{Conclusion}

Recent research suggests that better considering priority effects of both invasive and native species in restoration strategies could significantly help reducing invasive species colonization on disturbed areas. When invasive plants arrive or emerge earlier than natives, a size-related advantage can hamper native community restoration success, often impelling to reduce or remove invasive propagule sources. Yet, after removal, invasive plants can still threaten restoration success through persisting soil legacies, especially when the invasive species have long been present or when they were very abundant. The processes underlying the magnitude and persistence of soil legacies are however still poorly understood. Research efforts should be directed towards this topic, as well as towards developing cost-effective and 
rapid methods of assessing invasives-induced soil modifications. In order to avoid reinvasion and secondary invasions, invasive species removal must often be coupled with the restoration of native species. However, before undertaking revegetation, it is advisable to ensure that it will not lead to invasive species facilitation, such as in some harsh environments.

Invasion-resistance of restored native species could be increased by manipulating resource- and non-resource-based priority effects, especially in productive environments. Resource preemption, driving priority effects, may be enhanced by extending native species time advance over invasives and by manipulating the characteristics of the restored native species. Several studies reported a high benefit of giving only few weeks of advance, and the amplitude of the benefit was often correlated to variations in environmental conditions (e.g. climate, rainfall, soil fertility). Extending time advance showed mixed results and has been yet poorly studied, raising the need to multiply studies in order to define durations of time advance which are the most effective and how this effectiveness varies depending on environmental conditions. Resource preemption could also be enhanced by manipulating the characteristics of the restored species (selecting species having traits associated to strong and rapid resource preemption, increasing species diversity or sowing density), but such strategies remain largely untested in the field. Priority effects have also been suggested to be influenced by niche overlap between species, but attempts to use functional similarities to control invasive species often showed unsatisfying results. Focusing on key functional traits playing a substantial role in invasion success (e.g. phenology) appeared more promising, but studies are lacking to evaluate the relevance of this method. The manipulation of non-resource priority effects to limit invasions has been yet poorly studied. Restoring allelopathic native species may decrease invasion success by directly reducing the target invasive species biomass and indirectly facilitating native species. To investigate the potential of this method, research is needed on the interactions between allelopathy and priority effects as well as the use on the ability of native allelopathic species to suppress several invasive species. The manipulation of other non-resource mechanisms to increase priority effects of natives, such as natural enemies of invasive species or mycorrhizae, appears today premature.

Combinations between different priority effect-based strategies have not been explored yet, but may potentially enhance invasive species control. When invasive species are present, it may be relevant to simultaneously tackle their priority effects and increase those of desired native species. Different strategies could also be successively used over time. For example, establishing a community dominated by one competitive species, producing a high rate of biomass, may be an effective way to rapidly increase native cover and counter immediate 
invasion risk, while subsequently adding seeds from diverse species may help stabilize the community in the long term.

\section{Acknowledgements}

We gratefully thank D. Simberloff for his helpful comments, as well as M. Sweetko for reviewing the English. No conflicts of interest have been declared.

\section{Appendix A. Supplementary data}

Supplementary data to this article can be found online at https://doi.org/10.1016/j.ecoleng.2018.11.011.

\section{References}

Abraham, J.K., Corbin, J.D., D’Antonio, C.M., 2009. California native and exotic perennial grasses differ in their response to soil nitrogen, exotic annual grass density, and order of emergence. Plant Ecol. 201 (2), 445-456

Abrams, P., 1983. The theory of limiting similarity. Annu. Rev. Ecol. Syst. 14 (1), 359-376

Alpert, P., Maron, J.L., 2000. Carbon addition as a countermeasure against biological invasion by plants. Biol. Invas. 2 (1), 33-40

D'Antonio, C.M., Hughes, R.F., Vitousek, P.M., 2001. Factors influencing dynamics of two invasive C4 grasses in seasonally dry Hawaiian woodlands. Ecology 82 (1), 89-104

D'Antonio, C., Meyerson, L.A., 2002. Exotic plant species as problems and solutions in ecological restoration: a synthesis. Restor. Ecol. 10 (4), 703-713

D’Antonio, C.M., Ostertag, R., Cordell, S., Yelenik, S., 2017. Interactions among invasive plants: lessons from Hawaii. Annu. Rev. Ecol. Evol. Syst. 48, 521-541

Aronson, M.F.J., Galatowitsch, S., 2008. Long-term vegetation development of restored prairie pothole wetlands. Wetlands 28 (4), 883-895

Baer, S.G., Blair, J.M., Collins, S.L., Knapp, A.K., 2003. Soil resources regulate productivity and diversity in newly established tallgrass prairie. Ecology 84 (3), 724-735

Bais, H.P., Vepachedu, R., Gilroy, S., Callaway, R.M., Vivanco, J.M., 2003. Allelopathy and exotic plant invasion: from molecules and genes to species interactions. Science 301 (5638), 1377-1380

Bardgett, R.D., Wardle, D.A., 2010. Aboveground-Belowground Linkages: Biotic Interactions, Ecosystem Processes, and Global Change. Oxford University Press, Oxford, UK 
Becerra, P.I., Montenegro, G., 2013. The widely invasive tree Pinus radiata facilitates regeneration of native woody species in a semi-arid ecosystem. Appl. Veg. Sci. 16 (2), 173-183

Bever, J.D., 2003. Soil community feedback and the coexistence of competitors: conceptual frameworks and empirical tests. New Phytol. 157 (3), 465-473

Bezemer, T., Lawson, C.S., Hedlund, K., Edwards, A.R., Brook, A.J., Igual, J.M., Van Der Putten, W.H., 2006. Plant species and functional group effects on abiotic and microbial soil properties and plant-soil feedback responses in two grasslands. J. Ecol. 94 (5), 893-904

Bhowmik, P.C., 2003. Challenges and opportunities in implementing allelopathy for natural weed management. Crop Prot. 22 (4), 661-671

Blackshaw, R.E., O'donovan, J.T., Harker, K.N., Clayton, G.W., Stougaard, R.N., 2006. Reduced herbicide doses in field crops: a review. Weed Biol. Manage. 6 (1), 10-17

Blair, A.C., Hanson, B.D., Brunk, G.R., Marrs, R.A., Westra, P., Nissen, S.J., Hufbauer, R.A., 2005. New techniques and findings in the study of a candidate allelochemical implicated in invasion success. Ecol. Lett. 8 (10), 1039-1047

Blair, A.C., Nissen, S.J., Brunk, G.R., Hufbauer, R.A., 2006. A lack of evidence for an ecological role of the putative allelochemical ( \pm )- catechin in spotted knapweed invasion success. J. Chem. Ecol. 32 (10), 2327-2331

Blumenthal, D.M., Jordan, N.R., Russelle, M.P., 2003. Soil carbon addition controls weeds and facilitates prairie restoration. Ecol. Appl. 13 (3), 605-615

Buckley, Y.M., 2008. The role of research for integrated management of invasive species, invaded landscapes and communities. J. Appl. Ecol. 45 (2), 397-402

Buisson, E., Anderson, S., Holl, K.D., Corcket, E., Hayes, G.F., Peeters, A., Dutoit, T., 2008

Reintroduction of Nassella pulchra to California coastal grasslands: effects of topsoil removal, plant neighbour removal and grazing. Appl. Veg. Sci. 11 (2), 195-204

Byun, C., Lee, E.J., 2017. Ecological application of biotic resistance to control the invasion of an invasive plant, Ageratina altissima. Ecol. Evol. 7 (7), 2181-2192

Byun, C., Blois, S., Brisson, J., 2013. Plant functional group identity and diversity determine biotic resistance to invasion by an exotic grass. J. Ecol. 101 (1), 128-139

Callaway, R.M., Ridenour, W.M., 2004. Novel weapons: invasive success and the evolution of increased competitive ability. Front. Ecol. Environ. 2 (8), 436-443 
Callaway, R.M., Ridenour, W.M., Laboski, T., Weir, T., Vivanco, J.M., 2005. Natural selection for resistance to the allelopathic effects of invasive plants. J. Ecol. 93 (3), 576-583

Callaway, R.M., Thelen, G.C., Rodriguez, A., Holben, W.E., 2004. Soil biota and exotic plant invasion. Nature 427 (6976), 731

Carter, D.L., Blair, J.M., 2012. High richness and dense seeding enhance grassland restoration establishment but have little effect on drought response. Ecol. Appl. 22 (4), 1308-1319

Case, T.J., 1990. Invasion resistance arises in strongly interacting species-rich model competition communities. Proc. Natl. Acad. Sci. 87 (24), 9610-9614

Cavieres, L.A., Quiroz, C.L., Molina-Montenegro, M.A., Muñoz, A.A., Pauchard, A., 2005. Nurse effect of the native cushion plant Azorella monantha on the invasive non-native Taraxacum officinale in the high-Andes of central Chile. Persp. Plant Ecol. Evol System. 7 (3), 217-226

Chadwell, T.B., Engelhardt, K.A.M., 2008. Effects of pre-existing submersed vegetation and propagule pressure on the invasion success of Hydrilla verticillata. J. Appl. Ecol 45 (2), 515-523

Chase, J.M., 2003. Community assembly: when should history matter? Oecologia 136 (4), 489-498

Chase, J.M., 2007. Drought mediates the importance of stochastic community assembly. Proc. Natl. Acad. Sci. 104 (44), 17430-17434

Chase, J.M., 2010. Stochastic community assembly causes higher biodiversity in more productive environments. Science 328 (5984), 1388-1391

Chase, J.M., Myers, J.A., 2011. Disentangling the importance of ecological niches from stochastic processes across scales. Philos. Trans. Roy. Soc. B: Biol. Sci. 366 (1576), 2351-2363

Cleland, E.E., Esch, E., McKinney, J., 2015. Priority effects vary with species identity and origin in an experiment varying the timing of seed arrival. Oikos 124 (1), 33-40

Cleland, E.E., Larios, L., Suding, K.N., 2013. Strengthening invasion filters to reassemble native plant communities: soil resources and phenological overlap. Restor. Ecol. 21 (3), 390-398

Clewley, G.D., Eschen, R., Shaw, R.H., Wright, D.J., 2012. The effectiveness of classical biological control of invasive plants. J. Appl. Ecol. 49 (6), 1287-1295

Collinge, S.K., Ray, C., 2009. Transient patterns in the assembly of vernal pool plant communities. Ecology 90 (12), 3313-3323 
Corbin, J.D., D'Antonio, C.M., 2004a. Competition between native perennial and exotic annual grasses: implications for an historical invasion. Ecology 85 (5), 1273-1283

Corbin, J.D., D'Antonio, C.M., 2004b. Effects of exotic species on soil nitrogen cycling: implications for restoration. Weed Technol. 18 (1), 1464-1467

Corbin, J.D., D’Antonio, C.M., 2012. Gone but not forgotten? Invasive plants' legacies on community and ecosystem properties. Invasive Plant Sci. Manage. 5 (1), 117-124

Cox, R.D., Allen, E.B., 2008. Stability of exotic annual grasses following restoration efforts in southern California coastal sage scrub. J. Appl. Ecol. 45 (2), 495-504

Davis, M.A., Grime, J.P., Thompson, K., 2000. Fluctuating resources in plant communities: a general theory of invasibility. J. Ecol. 88 (3), 528-534

Davis, M.A., Pelsor, M., 2001. Experimental support for a resource-based mechanistic model of invasibility. Ecol. Lett. 4 (5), 421-428

Dawson, W., Fischer, M., van Kleunen, M., 2011. The maximum relative growth rate of common UK plant species is positively associated with their global invasiveness. Glob. Ecol. Biogeogr. 20 (2), 299-306

Dickie, I.A., St John, M.G., Yeates, G.W., Morse, C.W., Bonner, K.I., Orwin, K., Peltzer, D.A., 2014. Belowground legacies of Pinus contorta invasion and removal result in multiple mechanisms of invasional meltdown. AoB Plants 6

Dickson, T.L., Hopwood, J.L., Wilsey, B.J., 2012. Do priority effects benefit invasive plants more than native plants? An experiment with six grassland species. Biol. Invas 14 (12), 2617-2624

Dietz, H., Edwards, P.J., 2006. Recognition that causal processes change during plant invasion helps explain conflicts in evidence. Ecology 87 (6), 1359-1367

Dostálek, T., Pánková, H., Münzbergová, Z., Rydlová, J., 2013. The effect of AMF suppression on plant species composition in a nutrient-poor dry grassland. PLoS One 8 (11), e80535

Drenovsky, R.E., James, J.J., 2010. Designing invasion-resistant plant communities: the role of plant functional traits. Rangelands 32 (1), 32-37

Drew, T.J., Flewelling, J.W., 1979. Stand density management: an alternative approach and its application to Douglas-fir plantations. Forest Sci. 25 (3), 518-532

Dyer, A.R., Rice, K.J., 1997. Intraspecific and diffuse competition: the response of Nassella pulchra in a California grassland. Ecol. Appl. 7 (2), 484-492 
Dyer, A.R., Rice, K.J., 1999. Effects of competition on resource availability and growth of a California bunchgrass. Ecology 80 (8), 2697-2710

Ehrenfeld, J.G., 2003. Effects of exotic plant invasions on soil nutrient cycling processes. Ecosystems $6(6), 503-523$

Ehrenfeld, J.G., Ravit, B., Elgersma, K., 2005. Feedback in the plant-soil system. Annu Rev. Environ. Resour. 30, 75-115

Ejrnaes, R., Bruun, H.H., Graae, B.J., 2006. Community assembly in experimental Grasslands: Suitable environment or timely arrival? Ecology 87 (5), 1225-1233

Elton, C., 1958. The ecology of invasions by animals and plants. The Ecology of Invasions by Animals and Plants. University of Chicago Press, London, UK

Emery, S.M., 2007. Limiting similarity between invaders and dominant species in herbaceous plant communities? J. Ecol. 95 (5), 1027-1035

Eschen, R., Mortimer, S.R., Lawson, C.S., Edwards, A.R., Brook, A.J., Igual, J.M., Schaffner, U., 2007. Carbon addition alters vegetation composition on ex-arable fields. J. Appl. Ecol. 44 (1), $95-104$

Eviner, V.T., Hawkes, C.V., 2012. The effects of plant-soil feedbacks on invasive plants: mechanisms and potential management options. In: Invasive Plant Ecology and Management: Linking Processes to Practice. CABI Publishing, pp. 122-141

Fargione, J., Brown, C.S., Tilman, D., 2003. Community assembly and invasion: an experimental test of neutral versus niche processes. Proc. Natl. Acad. Sci. 100 (15), 8916-8920

Firn, J., MacDougall, A.S., Schmidt, S., Buckley, Y.M., 2010. Early emergence and resource availability can competitively favour natives over a functionally similar invader. Oecologia 163 (3), 775-784

Fitter, A., 2003. Making allelopathy respectable. Science 301 (5638), 1337-1338

Flinn, K.M., Kuhns, H.A.D., Mikes, J.L., Lonsdorf, E.V., Lake, J.K., 2017. Invasion and succession change the functional traits of serpentine plant communities. J. Torrey Bot. Soc. 144 (2), 109124

Fridley, J.D., Stachowicz, J.J., Naeem, S., Sax, D.F., Seabloom, E.W., Smith, M.D., Holle, B.V., 2007. The invasion paradox: reconciling pattern and process in species invasions. Ecology 88 (1), 3-17 
Fukami, T., 2015. Historical contingency in community assembly: integrating niches, species pools, and priority effects. Annu. Rev. Ecol. Evol. Syst. 46, 1-23

Funk, J.L., Cleland, E.E., Suding, K.N., Zavaleta, E.S., 2008. Restoration through reassembly: plant traits and invasion resistance. Trends Ecol. Evol. 23 (12), 695-703

Funk, J.L., Vitousek, P.M., 2007. Resource-use efficiency and plant invasion in low-resource systems. Nature 446 (7139), 1079

Gerhardt, F., Collinge, S.K., 2007. Abiotic constraints eclipse biotic resistance in determining invasibility along experimental vernal pool gradients. Ecol. Appl. 17 (3), 922-933

Gerlach, J.D., Rice, K.J., 2003. Testing life history correlates of invasiveness using congeneric plant species. Ecol. Appl. 13 (1), 167-179

Gioria, M., Osborne, B.A., 2014. Resource competition in plant invasions: emerging patterns and research needs. Front. Plant Sci. 5, 501

Goldberg, D.E., 1990. Components of resource competition in plant communities. In: Perspectives on Plant Competition. Academic press, London, pp. 27-49

Goldstein, L.J., Suding, K.N., 2014. Applying competition theory to invasion: resource impacts indicate invasion mechanisms in California shrublands. Biol. Invas. 16 (1), 191-203

Goslee, S.C., Veith, T.L., Skinner, R.H., Comas, L.H., 2013. Optimizing ecosystem function by manipulating pasture community composition. Basic Appl. Ecol. 14 (8), 630-641

Grman, E., Suding, K.N., 2010. Within-year soil legacies contribute to strong priority effects of exotics on native California grassland communities. Restor. Ecol. 18 (5), 664-670

Grove, S., Haubensak, K.A., Parker, I.M., 2012. Direct and indirect effects of allelopathy in the soil legacy of an exotic plant invasion. Plant Ecol. 213 (12), 1869-1882

Grove, S., Parker, I.M., Haubensak, K.A., 2015. Persistence of a soil legacy following removal of a nitrogen-fixing invader. Biol. Invas. 17 (9), 2621-2631

Grutters, B.M., Roijendijk, Y.O., Verberk, W.C., Bakker, E.S., 2017. Plant traits and plant biogeography control the biotic resistance provided by generalist herbivores. Funct Ecol. 31 (6), 1184-1192

Grotkopp, E., Erskine-Ogden, J., Rejmánek, M., 2010. Assessing potential invasiveness of woody horticultural plant species using seedling growth rate traits. J. Appl. Ecol. 47 (6), 1320-1328 
Hacker, S.D., Dethier, M.N., 2009. Differing consequences of removing ecosystem-modifying invaders: significance of impact and community context to restoration potential. In: Biological Invasions in Marine Ecosystems. Springer, Berlin, Heidelberg, pp 375-385

Halmer, P., 2004. Methods to improve seed performance in the field. In: Handbook of Seed Physiology. CRC Press, pp. 125-156

Hamman, S.T., Hawkes, C.V., 2013. Biogeochemical and microbial legacies of non-native grasses can affect restoration success. Restor. Ecol. 21 (1), 58-66

Hanslin, H.M., Kollmann, J., 2016. Positive responses of coastal dune plants to soil conditioning by the invasive Lupinus nootkatensis. Acta Oecologica 77, 1-9

Harms, R.S., Hiebert, R.D., 2006. Vegetation response following invasive tamarisk (Tamarix spp.) removal and implications for riparian restoration. Restor. Ecol. 14 (3), 461-472

Hartnett, D.C., Wilson, G.W., 1999. Mycorrhizae influence plant community structure and diversity in tallgrass prairie. Ecology 80 (4), 1187-1195

Hartnett, D.C., Wilson, G.W., 2002. The role of mycorrhizas in plant community structure and dynamics: lessons from grasslands. Plant Soil 244 (1-2), 319-331

Hawkes, C.V., Belnap, J., D’Antonio, C., Firestone, M.K., 2006. Arbuscular mycorrhizal assemblages in native plant roots change in the presence of invasive exotic grasses. Plant Soil 281 (1), 369380

Hayes, K.R., Barry, S.C., 2008. Are there any consistent predictors of invasion success? Biol. Invas. $10(4), 483-506$

Hazelton, E.L., Mozdzer, T.J., Burdick, D.M., Kettenring, K.M., Whigham, D.F., 2014. Phragmites australis management in the United States: 40 years of methods and outcomes. AoB Plants 6

Hector, A., Bell, T., Hautier, Y., Isbell, F., Kery, M., Reich, P.B., Schmid, B., 2011. BUGS in the analysis of biodiversity experiments: species richness and composition are of similar importance for grassland productivity. PLoS One 6 (3), e17434

Helsen, K., Hermy, M., Honnay, O., 2016. A test of priority effect persistence in seminatural grasslands through the removal of plant functional groups during community assembly. BMC Ecol. 16 (1), 22 
Herron, G.J., Sheley, R.L., Maxwell, B.D., Jacobsen, J.S., 2001. Influence of nutrient availability on the interaction between spotted knapweed and bluebunch wheatgrass. Restor. Ecol. 9 (3), 326331

Hill, B.C., Silvertown, J., 1997. Higher-order interaction between molluscs and sheep affecting seedling numbers in grassland. Acta Oecologica 18 (5), 587-596

Hobbs, R.J., Huenneke, L.F., 1992. Disturbance, diversity, and invasion: implications for conservation. Conserv. Biol. 6 (3), 324-337

Hölzel, N., Otte, A., 2004. Assessing soil seed bank persistence in flood-meadows: the search for reliable traits. J. Veg. Sci. 15 (1), 93-100

Hubbell, S.P., 2001. The unified neutral theory of biodiversity and biogeography. Monographs in population biology. Princeton University Press, Princeton

Huenneke, L.F., Hamburg, S.P., Koide, R., Mooney, H.A., Vitousek, P.M., 1990. Effects of soil resources on plant invasion and community structure in Californian serpentine grassland. Ecology 71 (2), 478-491

Iponga, D.M., Milton, S.J., Richardson, D.M., 2008. Superiority in competition for light: a crucial attribute defining the impact of the invasive alien tree Schinus molle (Anacardiaceae) in South African savanna. J. Arid Environ. 72 (5), 612-623

Jabran, K., 2017. Manipulation of Allelopathic Crops for Weed Control. Springer

Jabran, K., Mahajan, G., Sardana, V., Chauhan, B.S., 2015. Allelopathy for weed control in agricultural systems. Crop Prot. 72, 57-65

James, J.J., Drenovsky, R.E., Monaco, T.A., Rinella, M.J., 2011. Managing soil nitrogen to restore annual grass-infested plant communities: effective strategy or incomplete framework? Ecol. Appl. 21 (2), 490-502

Jiang, L., Brady, L., Tan, J., 2011. Species diversity, invasion, and alternative community states in sequentially assembled communities. Am. Nat. 178 (3), 411-418

Jordan, N.R., Aldrich-Wolfe, L., Huerd, S.C., Larson, D.L., Muehlbauer, G., 2012. Soiloccupancy effects of invasive and native grassland plant species on composition and diversity of mycorrhizal associations. Invas. Plant Sci. Manage. 5 (4), 494-505

Jordan, N.R., Larson, D.L., Huerd, S.C., 2008. Soil modification by invasive plants: effects on native and invasive species of mixed-grass prairies. Biol. Invasions 10 (2), 177-190 
Jordan, N.R., Zhang, J., Huerd, S., 2000. Arbuscular-mycorrhizal fungi: potential roles in weed management. Weed Res. 40 (5), 397-410

Kardol, P., Cornips, N.J., van Kempen, M.M., Bakx-Schotman, J.M., van der Putten, W.H., 2007. Microbe-mediated plant-soil feedback causes historical contingency effects in plant community assembly. Ecol. Monogr. 77 (2), 147-162

Kardol, P., Souza, L., Classen, A.T., 2013. Resource availability mediates the importance of priority effects in plant community assembly and ecosystem function. Oikos 122 (1), 84-94

Kellogg, C.H., Bridgham, S.D., 2002. Colonization during early succession of restored freshwater marshes. Can. J. Bot. 80 (2), 176-185

Kennedy, T.A., Naeem, S., Howe, K.M., Knops, J.M., Tilman, D., Reich, P., 2002. Biodiversity as a barrier to ecological invasion. Nature 417 (6889), 636

Klironomos, J.N., 2002. Feedback with soil biota contributes to plant rarity and invasiveness in communities. Nature 417 (6884), 67

Koide, R.T., Dickie, I.A., 2002. Effects of mycorrhizal fungi on plant populations. In: Diversity and Integration in Mycorrhizas. Springer, Dordrecht, pp. 307-317

Kolar, C.S., Lodge, D.M., 2001. Progress in invasion biology: predicting invaders. Trends Ecol. Evol. 16 (4), 199-204

Körner, C., Stöcklin, J., Reuther-Thiébaud, L., Pelaez-Riedl, S., 2008. Small differences in arrival time influence composition and productivity of plant communities. New Phytol. 177 (3), 698-705

Kourtev, P.S., Ehrenfeld, J.G., Häggblom, M., 2002. Exotic plant species alter the microbial community structure and function in the soil. Ecology 83 (11), 3152-3166

Keane, R.M., Crawley, M.J., 2002. Exotic plant invasions and the enemy release hypothesis. Trends Ecol. Evol. 17 (4), 164-170

Kulmatiski, A., Beard, K.H., 2006. Activated carbon as a restoration tool: potential for control of invasive plants in abandoned agricultural fields. Restor. Ecol. 14 (2), 251-257

Kulmatiski, A., Beard, K.H., 2011. Long-term plant growth legacies overwhelm short-term plant growth effects on soil microbial community structure. Soil Biol. Biochem. 43 (4), 823-830

Larson, D.L., Bright, J.B., Drobney, P., Larson, J.L., Palaia, N., Rabie, P.A., Wells, D., 2013. Using prairie restoration to curtail invasion of Canada thistle: the importance of limiting similarity and seed mix richness. Biol. Invas. 15 (9), 2049-2063 
Lavorel, S., Prieur-Richard, A.-H., Grigulis, K., 1999. Invasibility and diversity of plant communities: from patterns to processes. Divers. Distrib. 5 (1-2), 41-49

Leger, E.A., Baughman, O.W., 2015. What seeds to plant in the Great Basin? Comparing traits prioritized in native plant cultivars and releases with those that promote survival in the field. Natural Areas J. 35 (1), 54-68

Lenz, T.I., Facelli, J.M., 2003. Shade facilitates an invasive stem succulent in a chenopod shrubland in South Australia. Austral. Ecol. 28 (5), 480-490

Levine, J.M., Adler, P.B., Yelenik, S.G., 2004. A meta-analysis of biotic resistance to exotic plant invasions. Ecol. Lett. 7 (10), 975-989

Levine, J.M., D’Antonio, C.M., 1999. Elton revisited: a review of evidence linking diversity and invasibility. Oikos 15-26

Levine, J.M., Vila, M., Antonio, C.M., Dukes, J.S., Grigulis, K., Lavorel, S., 2003. Mechanisms underlying the impacts of exotic plant invasions. Proc. Royal Soc London B: Biol. Sci. 270 (1517), 775-781

Liu, H., Stiling, P., 2006. Testing the enemy release hypothesis: a review and meta-analysis. Biol. Invas. 8 (7), 1535-1545

Lockwood, J.L., Cassey, P., Blackburn, T., 2005. The role of propagule pressure in explaining species invasions. Trends Ecol. Evol. 20 (5), 223-228

Lonsdale, W.M., 1999. Global patterns of plant invasions and the concept of invasibility. Ecology 80 (5), 1522-1536

Lorenzo, P., Rodríguez-Echeverría, S., González, L., Freitas, H., 2010. Effect of invasive Acacia dealbata link on soil microorganisms as determined by PCR-DGGE. Appl. Soil Ecol. 44 (3), $245-251$

Mack, R.N., 1989. Temperate grasslands vulnerable to plant invasion: characteristics and consequences. In: Biological Invasions: A Global Perspective. Wiley, pp. 155-179

Mangla, S., Callaway, R.M., 2008. Exotic invasive plant accumulates native soil pathogens which inhibit native plants. J. Ecol. 96 (1), 58-67

Marchante, E., Kjøller, A., Struwe, S., Freitas, H., 2008. Short-and long-term impacts of Acacia longifolia invasion on the belowground processes of a Mediterranean coastal dune ecosystem. Appl. Soil Ecol. 40 (2), 210-217 
Marler, M.J., Zabinski, C.A., Callaway, R.M., 1999. Mycorrhizae indirectly enhance competitive effects of an invasive forb on a native bunchgrass. Ecology 80 (4), 1180-1186

Maron, J.L., Connors, P.G., 1996. A native nitrogen-fixing shrub facilitates weed invasion. Oecologia $105(3), 302-312$

Maron, J.L., Jefferies, R.L., 2001. Restoring enriched grasslands: effects of mowing on species richness, productivity, and nitrogen retention. Ecol. Appl. 11 (4), 1088-1100

Maron, J.L., Vilà, M., 2001. When do herbivores affect plant invasion? Evidence for the natural enemies and biotic resistance hypotheses. Oikos 95 (3), 361-373

Marushia, R.G., Cadotte, M.W., Holt, J.S., 2010. Phenology as a basis for management of exotic annual plants in desert invasions. J. Appl. Ecol. 47 (6), 1290-1299

Mason, T.J., French, K., Jolley, D., 2013. Arrival order among native plant functional groups does not affect invasibility of constructed dune communities. Oecologia 173 (2), 557-568

May, F.E., Ash, J.E., 1990. An assessment of the allelopathic potential of Eucalyptus. Aust J. Bot. 38 (3), 245-254

Meisner, A., Hol, W.H.G., de Boer, W., Krumins, J.A., Wardle, D.A., van der Putten, W.H., 2014. Plant-soil feedbacks of exotic plant species across life forms: a meta-analysis. Biol. Invas. 16 (12), 2551-2561

Middleton, E.L., Bever, J.D., Schultz, P.A., 2010. The effect of restoration methods on the quality of the restoration and resistance to invasion by exotics. Restor. Ecol. 18 (2), 181-187

Milakovic, I., Fiedler, K., Karrer, G., 2014. Management of roadside populations of invasive Ambrosia artemisiifolia by mowing. Weed Res. 54 (3), 256-264

Milchunas, D.G., Vandever, M.W., Ball, L.O., Hyberg, S., 2011. Allelopathic cover crop prior to seeding is more important than subsequent grazing/mowing in grassland establishment. Rangeland Ecol. Manage. 64 (3), 291-300

Mitchell, C.E., Agrawal, A.A., Bever, J.D., Gilbert, G.S., Hufbauer, R.A., Klironomos, J.N., Power, A.G., 2006. Biotic interactions and plant invasions. Ecol. Lett. 9 (6), 726-740

Mooney, H.A., 2005. Invasive alien species: the nature of the problem. In: Invasive Alien Species: A New Synthesis. Island press, Washington DC, pp. 1-11 
Morrison, W.E., Hay, M.E., 2011. Herbivore preference for native vs. exotic plants: generalist herbivores from multiple continents prefer exotic plants that are evolutionarily naïve. PLoS One $6(3), \mathrm{e} 17227$

Munter, E.J., 2008. Seasonal Prescribed fire Effects on Cheatgrass and Native Mixed Grass prairie Vegetation. Doctoral dissertation. State College, Chadron

Novoa, A., González, L., Moravcová, L., Pyšek, P., 2013. Constraints to native plant species establishment in coastal dune communities invaded by Carpobrotus edulis: implications for restoration. Biol. Conserv. 164, 1-9

Ooi, M.K., 2007. Dormancy classification and potential dormancy-breaking cues for shrub species from fire-prone south-eastern Australia. In: Seeds: Biology, Development and Ecology. Cabi, Cambridge, Wallingford, pp. 205-216

Parepa, M., Bossdorf, O., 2016. Testing for allelopathy in invasive plants: it all depends on the substrate!. Biol. Invas. 18 (10), 2975-2982

Parker, J.D., Hay, M.E., 2005. Biotic resistance to plant invasions? Native herbivores prefer nonnative plants. Ecol. Lett. 8 (9), 959-967

Pearson, D.E., Ortega, Y.K., Runyon, J.B., Butler, J.L., 2016. Secondary invasion: the bane of weed management. Biol. Conserv. 197, 8-17

Perry, L.G., Blumenthal, D.M., Monaco, T.A., Paschke, M.W., Redente, E.F., 2010. Immobilizing nitrogen to control plant invasion. Oecologia 163 (1), 13-24

Perry, L.G., Cronin, S.A., Paschke, M.W., 2009. Native cover crops suppress exotic annuals and favor native perennials in a greenhouse competition experiment. Plant Ecol. 204 (2), 247-259

Perry, L.G., Galatowitsch, S.M., 2006. Light competition for invasive species control: a model of cover crop-weed competition and implications for Phalaris arundinacea control in sedge meadow wetlands. Euphytica 148 (1-2), 121-134

Perry, L.G., Johnson, C., Alford, E.R., Vivanco, J.M., Paschke, M.W., 2005. Screening of grassland plants for restoration after spotted knapweed invasion. Restor. Ecol. 13 (4), 725-735

Perry, L.G., Neuhauser, C., Galatowitsch, S.M., 2003. Founder control and coexistence in a simple model of asymmetric competition for light. J. Theor. Biol. 222 (4), 425-436 
Petruzzella, A., Grutters, B., Thomaz, S.M., Bakker, E.S., 2017. Potential for biotic resistance from herbivores to tropical and subtropical plant invasions in aquatic ecosystems. Aquatic Invas. 12 (3)

Prati, D., Bossdorf, O., 2004. Allelopathic inhibition of germination by Alliaria petiolata (Brassicaceae). Am. J. Bot. 91 (2), 285-288

Petraitis, P.S., 1989. The representation of niche breadth and overlap on Tilman's consumer- resource graphs. Oikos 289-292

Pianka, E.R., 1974. Niche overlap and diffuse competition. Proc. Natl. Acad. Sci. 71 (5), 2141-2145

Price, J.N., Pärtel, M., 2013. Can limiting similarity increase invasion resistance? A metaanalysis of experimental studies. Oikos 122 (5), 649-656

Pyšek, P., Richardson, D.M., 2008. Traits associated with invasiveness in alien plants: where do we stand? In: Biological Invasions. Springer, Berlin, Heidelberg, pp 97-125

Regulation (EU) No 1143/2014 of the European Parliament and of the Council of 22 October 2014 on the prevention and management of the introduction and spread of invasive alien species

Reigosa, M.J., Pedrol, N., González, L., 2006. Allelopathy: a physiological process with ecological implications. Springer Science \& Business Media, Netherlands

Reinhart, K.O., Callaway, R.M., 2006. Soil biota and invasive plants. New Phytol. 170 (3), 445-457

Rejmánek, M., Richardson, D.M., 1996. What attributes make some plant species more invasive? Ecology 77 (6), 1655-1661

Reynolds, S.A., Corbin, J.D., D'Antonio, C.M., 2001. The effects of litter and temperature on the germination of native and exotic grasses in a coastal California grassland Madrono 230-235

Richardson, D.M., Pyšek, P., Rejmánek, M., Barbour, M.G., Panetta, F.D., West, C.J., 2000 Naturalization and invasion of alien plants: concepts and definitions. Divers. Distrib 6 (2), 93107

Rinaudo, V., Bàrberi, P., Giovannetti, M., van der Heijden, M.G., 2010. Mycorrhizal fungi suppress aggressive agricultural weeds. Plant Soil 333 (1-2), 7-20

Robinson, G.R., Quinn, J.F., Stanton, M.L., 1995. Invasibility of experimental habitat islands in a California winter annual grassland. Ecology 76 (3), 786-794 
Rodriguez-Echeverria, S., Afonso, C., Correia, M., Lorenzo, P., Roiloa, S.R., 2013. The effect of soil legacy on competition and invasion by Acacia dealbata Link. Plant Ecol 214 (9), 1139-1146

Ross, M.A., Harper, J.L., 1972. Occupation of biological space during seedling establishment. J. Ecol. $77-88$

Sax, D.F., Brown, J.H., 2000. The paradox of invasion. Glob. Ecol. Biogeogr. 9 (5), 363-371

Seabloom, E.W., Harpole, W.S., Reichman, O.J., Tilman, D., 2003. Invasion, competitive dominance, and resource use by exotic and native California grassland species. Proc Natl. Acad. Sci. 100 (23), 13384-13389

Shea, K., Chesson, P., 2002. Community ecology theory as a framework for biological invasions. Trends Ecol. Evol. 17 (4), 170-176

Simberloff, D., 2013. Biological invasions: much progress plus several controversies. Contrib. Sci. 9 (2013), 7-16

Smith, S.E., Read, D.J., 2008. Mycorrhizal symbiosis, 3rd ed. Academic press, San Diego, USA

Smith, M.R., Charvat, I., Jacobson, R.L., 1998. Arbuscular mycorrhizae promote establishment of prairie species in a tallgrass prairie restoration. Can. J. Botany 76 (11), 1947-1954

Stevens, J.M., Fehmi, J.S., 2009. Competitive effect of two nonnative grasses on a native grass in southern Arizona. Invas. Plant Sci. Manage. 2 (4), 379-385

Stinson, K.A., Campbell, S.A., Powell, J.R., Wolfe, B.E., Callaway, R.M., Thelen, G.C., Klironomos, J.N., 2006. Invasive plant suppresses the growth of native tree seedlings by disrupting belowground mutualisms. PLoS Biol. 4 (5), e140

Stock, W.D., Wienand, K.T., Baker, A.C., 1995. Impacts of invading N 2-fixing Acacia species on patterns of nutrient cycling in two Cape ecosystems: evidence from soil incubation studies and 15 N natural abundance values. Oecologia 101 (3), 375-382

Stuble, K.L., Souza, L., 2016. Priority effects: natives, but not exotics, pay to arrive late. J Ecol. 104 (4), 987-993

Suding, K.N., Gross, K.L., Houseman, G.R., 2004. Alternative states and positive feedbacks in restoration ecology. Trends Ecol. Evol. 19 (1), 46-53

Symons, C.C., Arnott, S.E., 2014. Timing is everything: priority effects alter community invasibility after disturbance. Ecol. Evol. 4 (4), 397-407 
Symstad, A.J., 2000. A test of the effects of functional group richness and composition on grassland invasibility. Ecology 81 (1), 99-109

Temperton, V.M., 2004. Assembly Rules and Restoration Ecology: Bridging the Gap Between Theory and Practice, vol. 5 Island Press, Washington, DC

Thorpe, A.S., Thelen, G.C., Diaconu, A., Callaway, R.M., 2009. Root exudate is allelopathic in invaded community but not in native community: field evidence for the novel weapons hypothesis. J. Ecol. 97 (4), 641-645

Tilman, D., 1990. In: Grace, J., Tilman, D. (Eds.), Perspectives on Plant Competition. Academic Press, San Diego, pp. 117-141

Tilman, D., 1997. Community invasibility, recruitment limitation, and grassland biodiversity. Ecology $78(1), 81-92$

Turnbull, L.A., Rahm, S., Baudois, O., Eichenberger-Glinz, S., Wacker, L., Schmid, B., 2005. Experimental invasion by legumes reveals non-random assembly rules in grassland communities. J. Ecol. 93 (6), 1062-1070

van der Heijden, M.G., Klironomos, J.N., Ursic, M., Moutoglis, P., Streitwolf-Engel, R., Boller, T., Sanders, I.R., 1998. Mycorrhizal fungal diversity determines plant biodiversity, ecosystem variability and productivity. Nature 396 (6706), 69

van der Putten, W.H., Bardgett, R.D., Bever, J.D., Bezemer, T.M., Casper, B.B., Fukami, T., Wardle, D.A., 2013. Plant-soil feedbacks: the past, the present and future challenges. J. Ecol. 101 (2), 265-276

Vance, R.R., 1984. Interference competition and the coexistence of two competitors on a single limiting resource. Ecology 1349-1357

Vannette, R.L., Fukami, T., 2014. Historical contingency in species interactions: towards niche-based predictions. Ecol. Lett. 17 (1), 115-124

Vatovec, C., Jordan, N., Huerd, S., 2005. Responsiveness of certain agronomic weed species to arbuscular mycorrhizal fungi. Renew. Agric. Food Syst. 20 (3), 181-189

Vaughn, K.J., Young, T.P., 2015. Short-term priority over exotic annuals increases the initial density and longer-term cover of native perennial grasses. Ecol. Appl. 25 (3), 791-799

Veiga, R.S., Jansa, J., Frossard, E., van der Heijden, M.G., 2011. Can arbuscular mycorrhizal fungi reduce the growth of agricultural weeds? PLoS One 6 (12), e27825 
Viana, D.S., Cid, B., Figuerola, J., Santamaría, L., 2016. Disentangling the roles of diversity resistance and priority effects in community assembly. Oecologia 182 (3), 865-875

Vila, M., Weiner, J., 2004. Are invasive plant species better competitors than native plant species?evidence from pair-wise experiments. Oikos 105 (2), 229-238

Vink, S.N., Jordan, N.R., Huerd, S.C., Shaeffer, C.C., Kinkel, L.L., Aldrich-Wolfe, L., 2015. Soil conditioning effects of native and exotic grassland perennials on the establishment of native and exotic plants. Plant Soil 393 (1-2), 335-349

Vitousek, P.M., D'Antonio, C.M., Loope, L.L., Rejmanek, M., Westbrooks, R., 1997. Introduced species: a significant component of human-caused global change. N. Z. J Ecol. 21 (1), 1-16

von Gillhaussen, P., Rascher, U., Jablonowski, N.D., Plückers, C., Beierkuhnlein, C., Temperton, V.M., 2014. Priority effects of time of arrival of plant functional groups override sowing interval or density effects: a grassland experiment. PloS one 9 (1), e86906

Wainwright, C.E., Wolkovich, E.M., Cleland, E.E., 2012. Seasonal priority effects: implications for invasion and restoration in a semi-arid system. J. Appl. Ecol. 49 (1), 234-241

Wang, B., Qiu, Y.L., 2006. Phylogenetic distribution and evolution of mycorrhizas in land plants. Mycorrhiza 16 (5), 299-363

Wardle, D.A., 2001. Experimental demonstration that plant diversity reduces invasibility- evidence of a biological mechanism or a consequence of sampling effect? Oikos 95 (1), 161-170

Weidenhamer, J.D., Hartnett, D.C., Romeo, J.T., 1989. Density-dependent phytotoxicity: distinguishing resource competition and allelopathic interference in plants. J. Appl Ecol. 613624

Weiner, J., 1990. Asymmetric competition in plant populations. Trends Ecol. Evol. 5 (11), 360-364

Werner, C.M., Vaughn, K.J., Stuble, K.L., Wolf, K., Young, T.P., 2016. Persistent asymmetrical priority effects in a California grassland restoration experiment. Ecol. Appl 26 (6), 1624-1632

Williamson, M., 1999. Invasions. Ecography 22 (1), 5-12

Wilsey, B.J., Barber, K., Martin, L.M., 2015. Exotic grassland species have stronger priority effects than natives regardless of whether they are cultivated or wild genotypes. New Phytol. 205 (2), 928-937

Wolf, K.M., Young, T.P., 2016. Summer water in a restored native grassland flushes annual grass seed bank but fails to increase native perennial cover. Ecosphere 7 (6), 1309-1309 
972 Wolkovich, E.M., Cleland, E.E., 2011. The phenology of plant invasions: a community ecology perspective. Front. Ecol. Environ. 9 (5), 287-294

974

975

976

977

978

979

980

981

982

983

984

985

986

987

988

989

990

991

992

993

Xiong, W., Yu, D., Wang, Q., Liu, C., Wang, L., 2008. A snail prefers native over exotic freshwater plants: implications for the enemy release hypotheses. Freshw. Biol. 53 (11), 2256-2263

Yannelli, F.A., Hughes, P., Kollmann, J., 2017. Preventing plant invasions at early stages of revegetation: the role of limiting similarity in seed size and seed density. Ecol. Eng. 100, 286290

Yelenik, S.G., D'Antonio, C.M., 2013. Self-reinforcing impacts of plant invasions change over time. Nature 503 (7477), 517

Yelenik, S.G., Stock, W.D., Richardson, D.M., 2007. Functional group identity does not predict invader impacts: differential effects of nitrogen-fixing exotic plants on ecosystem function. Biol. Invas. 9 (2), 117-125

Young, T.P., Chase, J.M., Huddleston, R.T., 2001. Community succession and assembly comparing, contrasting and combining paradigms in the context of ecological restoration. Ecol. Restor. 19 (1), $5-18$

Young, T.P., Stuble, K.L., Balachowski, J.A., Werner, C.M., 2016. Using priority effects to manipulate competitive relationships in restoration. Restor. Ecol. 25 (S2)

Young, T.P., Zefferman, E.P., Vaughn, K.J., Fick, S., 2015. Initial success of native grasses is contingent on multiple interactions among exotic grass competition, temporal priority, rainfall and site effects. AoB Plants 7

Zhang, Y., Meng, H., Wang, Y., He, Q., 2018. Herbivory enhances the resistance of mangrove forest to cordgrass invasion. Ecology 99 (6), 1382-1390 